\title{
The Factors Affecting the E-commerce Adoption in SMEs in the Industrial Towns of Zanjan-Iran: Managers' Perspectives
}

\author{
Ali Reza Araste (M.A Candidate) \\ Management Department, Islamic Azad University, UAE Branch, UAE \\ E-mail: alireza.arasteh@gmail.com
}

Ali Mansouri (Ph.D)

Member, Assistant Professor, Management Department, Zanjan University, Iran

\section{Mostafa Jafari (Ph.D)}

Member, assistant professor, Management Department, Zanjan University, Iran

DOI: 10.6007/IJARBSS/v3-i10/280 URL: http://dx.doi.org/10.6007/IJARBSS/v3-i10/280

\begin{abstract}
Today, small and medium-sized enterprises have a large share in the industrial activities at various countries of the world. Also, small and medium-sized enterprises in the industrial towns of Zanjan have a significant share of industrial production. Currently, these firms have many structural, legal, technological, financial, and other problems and are not able to produce competitive products in world's markets. It seems that e-commerce is one of the strategies to improve the status of these firms to compete in global markets. This study aimed to provide a comprehensive insight into the factors affecting the adoption process of electronic commerce by small and medium-sized enterprises. The researches show that factors such as Intensity of competition, organizational characteristics, strategic orientation, innovation, managers' features, and information technology in small and medium-sized enterprises affect the ecommerce adoption. Hence, the relationship between these variables and adoption of ecommerce was examined in terms of research hypotheses. This study was a descriptive - survey research. The data was collected from the library and researcher-made questionnaire. Pearson correlation and Kendall Tao tests were used to determine the significance of the relationship between predictor and criterion variables. Also, regression, Friedman, and some other tests were used for obtaining other results. The results indicate that there is significant relationship between organizational characteristics, strategic orientation, level of innovation, characteristics of managers, information technology, and e-commerce adoption. The results of this study can be used by the managers of industrial towns at Zanjan, directors and managers of these firms for promoting the adoption of e-commerce in the region, managers of small and medium-sized enterprises, and managers of other industrial towns of Iran.

Keywords: e-commerce, internet, small and medium-sized enterprises, innovation adoption, Zanjan, industrial towns
\end{abstract}




\section{Introduction}

Industrial sector is one of the key sectors of economic activity in the world. Like other sectors, this sector has large, medium and small companies that compete with each other for success. Small firms have a large share in the industrial activity in different countries; they are mostly private. As a developing country, Iran is seeking to decrease the reliance on oil and increase non-oil exports; then, industry is of particular importance in Iran, because the activity of other sectors depends on this vital sector. The share of small firms in the industrial production of Iran is significant and, therefore, should be considered by the government. Small firms in Iran have encountered with structural, legal, technology, finance, and other problems and are not able to produce competitive products in global markets (Sadeghi etal.2005).

The main features of globalization are the world's growing business economy, financial liberalization, privatization, de-regulations, and facilitation of rapid and irreversible increase in information and communication technologies. It has lead to the creation of new businesses and the expansion of trade and the emergence of new forms of competition in the business world. In this context, small and medium enterprises in developing countries supported by local markets face a ruthless international competition that have endangered dynamic economic and technological development, especially access to financial resources, technical advice, information, specialized skills, technology, and the market. On the other hand, globalization has expanded the uncertainty about potential opportunities for small and medium enterprises to increase competitive actions and gain interests due to the knowledge and expertise based economy.In this regard, one of the most efficient strategies that developing countries have chosen to enter international markets was developing small and medium enterprises. According to the Clause 19 of the First Development Plan, the creation of small and medium enterprises was allowed. Then, industrial towns of Zanjan were established with following purposes: construction and development of public services, economic development, foreign and domestic investments, healthy and productive employment opportunities, labor and commodity market planning, production and export promotion, active participation in regional and global markets, using new technologies and transferring technical knowledge to the local production sector in line with scientific and technological developments in the world, accelerating the trade, economic and technological processes with the appropriate platform for testing the designs and extending them to the whole country with active interaction with the world and consistent with the twenty-year vision. E-commerce is developing in the world and influencing all industries. This phenomenon has been expanding because of using the Internet worldwide (Elahi et al, 2008).

Given the importance of e-commerce in Iran, special attention has been paid to the development of it like establishing e-commerce development office in the Ministry of Commerce and numerous national and international conferences in this field. In this context, identifying factors affecting the adoption of e-commerce can be one of the basic steps for ecommerce development in Iran.

Today, E-commerce is one of the important topics that researchers have focused on it. Articles, books, conferences and much research have been done in this regard. E-Commerce provides unique opportunities for developing countries to compete in the world economy (Gunrathe, 1997). 
Therefore, identification of e-commerce aspects leading to greater success in our country and directing funds for infrastructure development in this area is one of the most important issues for research that will be discussed briefly. As was mentioned above, today's small and medium enterprises have a large share of industrial activities in different countries; and Iran is not an exception. The integration of electronic commerce in the business activities of small and medium sized business owners and managers make changes in the method of business and acceptance of new technologies; thereby, small and medium enterprises grow and this help to reduce the gap between developed and developing countries. However, the adoption of ecommerce in small and medium-sized firms may put them in a better position in competitions of global markets (Nasko et al, 2008).

Turban et al (2008) investigated the impact of organizational incentives on development of ecommerce in India. Their research method was qualitative - analytical and exploratory. Their research population consisted of 4 Indian firms in the field of financial services and data collecting method, face-to-face interview, Information of Industry, and the report of newspapers, articles, and commercial documents. According to the results of this study, organizational incentives influencing the development of e-commerce are:

a)The role of managers and leaders, b) organizational characteristics, c) characteristics of information systems professionals (indirect cause)

McGregor (2006) presented a classification of barriers to the adoption of e-commerce. According to the research results, classification of barriers to adoption of e-commerce includes: A)Difficult barriers to electronic commerce - the barriers that cause the company to fail in adopting e-commerce- such as lack of technical skills and knowledge in the organization, complex implementation of e-commerce in the organization, the need to high investment, lack of enough time to implement e-commerce, difficulty in choosing to adopt various strategies for e-commerce, and security issues. B) Inappropriate barriers to e-commerce - the barriers that are inappropriate for organizations and lead them to impairment in adopting the e-commercesuch as incompatibility of e-commerce with products and services, trade incompatibility.

In a study titled "Electronic commerce development in small and medium-sized enterprises", SubbaRoa, Glenn Metts\& Mora Mong(2003) provided a model and investigated its applications in small and medium-sized enterprises. There are four stages for this model including existence, portals, integration of exchanges, and integration of firms; each stage has its own possibilities and obstacles. In this study, a sample of 153 companies from eight industry and 17 countries were evaluated. For describing the process of classifying, 4 companies from Australia and 3 companies from United States were selected. Accordingly, the researchers in this study will investigate which of the barriers are important factors in the realization of e-commerce in the industrial town of Zanjan- as one of the major industrial sectors in Iran.

\section{Methodology}

The present study was an applied and descriptive survey. The population consisted of all the managers of small and medium enterprises in the industrial city of Zanjan who were active during the period of study. The number of small and medium enterprises in the industrial city of Zanjan was 375; of which 185 units were active in several industries including transformers manufacturing, auto parts and medical supplies. Since most of the small and medium-sized 
enterprises which was active in the industrial city of Zanjan had been concentrated in a location and the total number of studied firms was low, the census is used. Field data was collected through questionnaires. This questionnaire consisted of 40 questions. The questionnaire was based on theoretical principles of the study and its different parts were designed using some other questionnaires.

The face validity was used for evaluating the validity of study. The questionnaires were distributed among the supervisor professors, consultant professors, faculty members, and a number of other experts. They were asked about the questions; after modifications, all of them confirmed the questionnaire. Cronbach's alpha was used for assessing the reliability of the questionnaire. First, pilot test was used and 15 questionnaires were distributed among the managers of small and medium-sized firms in industrial towns of Zanjan. The results were analyzed using the software 16SPSS. The test results showed that the reliability of the questionnaire was 0.81 ; this indicates the reliability of questionnaire is sufficient.

The descriptive statistics such as frequency tables, percentage, mean, variance, and standard deviation was used. Also, the inferential statistics such as the test of significance $r$, the test of significance $F$, the test of significance chi-square $(2 \chi)$, the test of significance $t$, and the test of significance $F$ was used for testing the correlation, Analysis of Variance (ANOVA), Friedman test, independent t-test, and the fitness of regression model, and significance of determination coefficient, respectively.

\section{Findings}

The analysis showed that of total of 98 managers- 83 (84.7\%) -were male and only 15 (15.3\%) were women. As was predictable, most of the managers were men. Most of the managers (38.77\%) had a bachelor degree. Since 79 (58\% ) of respondents were educated, the quality of the answers to the questionnaire was desirable. Also, of 98 managers, the majority were under 30 years old (29.59\%). The highest frequency of 34 subjects (34.69\%) was for managers who were managing affairs between 5 to 10 years. Also, more than 64 percent of the respondents were managers who were less than 10 years in managerial positions. Therefore, majority of respondents were managers who had little management experience. Most of the firms have between 5 to 10 employees (about 42\%). As can be seen, most of the companies have annual sales from 600 to 1000 million Iranian rials (35.71\%).According to the findings, the highest rate of production is related to metal products (18.36\%), chemical products (16.32\%), rubber and plastics (14.28\%), and food and drink industry (12.24 percent). Also, 75 (over $76 \%$ ) of firms are active in the industrial town of Zanjan for less than 10 years. Therefore, most of them are new firms have started their activities recently. Most of the firms have less than 3 computers (67.34 \%). It can be seen that only 39(79\% ) of firms have a website and Weblog. Compared to having a website, there are more companies with e-mail (over 58\%).

As can be seen, over 62 percent of firms use the Internet to do business affairs. The results indicate that the number of skilled employees in the computer field is desirable. As can be seen, 52.04 percent of the firms have employed skilled staffs in this field. Table 1 shows the relationship between the intensity of competition and adoption of e-commerce. 
Table 1: The correlation between intensity of competition and the adoption of e-commerce

\begin{tabular}{|r|l|l|l|}
\hline Variables & Correlation & Sig & Number \\
\cline { 1 - 3 } intensity of competition & 0.650 & 0.001 & 98 \\
\hline adoption of e-commerce & & & \\
\hline
\end{tabular}

As the table shows, there is a significant and positive relationship between the intensity of competition and the adoption of electronic commerce in the level of $p<0.01$. As a result, the null hypothesis $(\mathrm{HO})$ is rejected and the first hypothesis is confirmed.

Table 2 presents the relationship between organizational complexity and e-commerce adoption in small and medium-sized firms.

Table 2: The correlation between organizational complexity and adoption of e-commerce

\begin{tabular}{|r|l|l|l|}
\hline Variables & Correlation & Sig & Number \\
\cline { 1 - 3 } organizational complexity & \multirow{2}{*}{0.333} & 0.030 & 98 \\
\hline adoption of e-commerce & & & \\
\hline
\end{tabular}

According to the above table, it can be concluded that the correlation between organizational complexity and adoption of e-commerce is 0.333 and is significant at $p<0.05 \quad(p=0.030)$. Therefore, $\mathrm{HO}$ is rejected and the second research hypothesis is confirmed. It can be said that there is a positive relationship between organizational complexity and the adoption of electronic commerce in small and medium-sized enterprises.

The relationship between strategic trends of organization and e-commerce adoption in small and medium-sized enterprises is represented at the following.

Table 3: The correlation between strategic trends of organization and adoption of e-commerce

\begin{tabular}{|r|l|l|l|}
\hline Variables & Correlation & Sig & Number \\
\cline { 1 - 4 } strategic trends & \multirow{2}{|c|}{0.059} & 0.565 & 98 \\
\hline adoption of e-commerce & & & \\
\hline
\end{tabular}

As the table shows, the correlation between strategic trends of organization and adoption of ecommerce is 0.059 and is not significant at the $p<0.05$. The results show that there is no relationship between two variables. Therefore, $\mathrm{HO}$ is confirmed and research hypothesis is rejected. 
Table 4 shows the relationship between the level of innovation in small and medium-sized enterprises and adoption of e-commerce.

Table 4: The correlation between the level of innovation and adoption of e-commerce

\begin{tabular}{|r|l|l|l|}
\hline Variables & Correlation & Sig & Number \\
\cline { 1 - 3 } innovation & 0.536 & 0.001 & 98 \\
\hline adoption of e-commerce & & & 9 \\
\hline
\end{tabular}

As the table shows, the correlation between the level of innovation and adoption of ecommerce in small and medium-sized enterprises is 0.536 and is significant at $p<0.01$. As a result, $\mathrm{HO}$ is rejected and the fourth hypothesis is confirmed. Therefore, it can be said that there is positive relationship between the level of innovation and adoption of e-commerce by small and medium-sized enterprises.

The relationship between the characteristics of manager at small and medium-sized enterprises and e-commerce adoption by them is presented in Table 5.

Table 5: The correlation between the characteristics of managers and the adoption of ecommerce

\begin{tabular}{|r|l|l|l|}
\hline Variables & Correlation & Sig & Number \\
\cline { 1 - 4 } characteristics of managers & \multirow{2}{*}{0.698} & 0.001 & 98 \\
\hline adoption of e-commerce & & & \\
\hline
\end{tabular}

As the table shows, the correlation between the characteristics of managers and adoption of ecommerce in small and medium-sized enterprises is 0.698 and is significant at $p<0.01$. As a result, $\mathrm{HO}$ is rejected and the hypothesis is confirmed. Therefore, it can be said that there is positive relationship between the characteristics of managers and adoption of e-commerce by small and medium-sized enterprises.

The relationship between the information technology equipments at small and medium-sized enterprises and e-commerce adoption by them is presented in Table 6.

Table 6: The correlation between the information technology and the adoption of e-commerce

\begin{tabular}{|c|l|l|l|}
\hline Variables & Correlation & Sig & Number \\
\hline information technology & 0.743 & 0.001 & 98 \\
\hline adoption of e-commerce & & & \\
\hline
\end{tabular}

As the table shows, the correlation between the information technology and adoption of ecommerce in small and medium-sized enterprises is 0.743 and is significant at $p<0.01$. As a 
result, $\mathrm{HO}$ is rejected and the hypothesis is confirmed. Therefore, it can be said that there is positive relationship between the information technology equipments and adoption of ecommerce by small and medium-sized enterprises.

Table 7 examines the prioritization of strategies by managers of small and medium-sized enterprises in industrial towns of Zanjan.

Table 7: Friedman test

\begin{tabular}{|r|r|}
\hline 98 & Number \\
\hline 16.345 & $\left(\chi^{2}\right)$ \\
2 & $d f$ \\
0.001 & Sig. \\
\hline
\end{tabular}

As can be seen in

Table 8: Ranking of strategies in Friedman test

\begin{tabular}{|r|r|}
\hline Ranks mean & \\
\hline 1.55 & Cost cut strategy \\
1.86 & Differentiation strategy \\
2.59 & Focus strategy \\
\hline
\end{tabular}

Table 7, because significance index is less than $0.01, \mathrm{HO}$ is rejected and $\mathrm{H} 1$ is confirmed at significance level of 0.01 . Therefore, there is a significant difference between the prioritization of strategies by managers of small and medium-sized enterprises at industrial towns of Zanjan. Table 8 shows the ranking of strategies in the order of importance as following:

1 -cost reduction strategies, 2 - differentiation strategy

The first priority for most companies is cost reduction strategies.

\section{Discussion and conclusions}

The first hypothesis stated that there is positive relationship between the intensity of competition and the adoption of e-commerce in small and medium-sized enterprises. Based on the results of first hypothesis analysis, there is not significant relationship between competition intensity and level of e-commerce adoption. This is consistent with the findings of Lin (2006), Wang and Cheng (2004); however, it is inconsistent with the results of Gslar and Grover (1993), and Wang (2001).

The second hypothesis stated that there is significant and positive relationship between organizational complexity and the adoption of electronic commerce in small and medium-sized firms. Based on the results of second hypothesis analysis, the probability of adopting ecommerce in small and medium-sized enterprises with greater organizational complexity is higher. This is consistent with the findings of Vilaska et al, (2007). According to the results, it 
can be said that small and medium-sized enterprises with complex organizational design form strategic alliances with other companies, work in several markets, manage their activities through knowledge instead of using the hierarchy, have the flexibility to do things as a team, and decide rapidly to adapt to global changes such as increasing use of internet as a communication and exchange medium.

The third hypothesis stated that there is significant and positive relationship between strategic orientation of organizations and the adoption of electronic commerce in small and mediumsized firms. Based on the results of third hypothesis analysis, there is significant relationship between the strategic orientation of organization and adopting of e-commerce in small and medium-sized enterprises. This is consistent with the findings of Vilaska et al, (2007); however, it is inconsistent with the findings of Gslar and Grover. The results suggest that firms that have chosen differentiation strategy as their first strategy are more likely to adopt e-commerce than firms that chosen cost reduction strategy as their first strategy.

The fourth hypothesis stated that there is positive relationship between the level of innovation and adoption of e-commerce by small and medium-sized enterprises. Based on the results of the fourth hypothesis analysis, there is significant and positive relationship between the level of innovation in small and medium-sized enterprises and adoption of e-commerce. This is consistent with the findings of Vilaska and colleagues, Wang and Cheng, and Wang. This can be explained by saying that the Internet as a new distribution channel for companies with high innovation in products, processes, and organizational design is of high desirability; these organizations use it faster than other companies to promote their businesses.

The fifth hypothesis stated that there is positive relationship between the characteristics of managers in small and medium-sized firms and adoption of electronic commerce by them. Based on the results of the fifth hypothesis analysis, there is significant relationship between the characteristics of managers in small and medium-sized enterprises and adoption of ecommerce. This is consistent with the findings of Wang and colleagues, and Vilaska. In explaining this relationship, it can be said that the managers who tend to experience and take higher risk are more likely to use the e-commerce. The people who tend to experience are willing to search innovations; and Internet is a phenomenon that has the above characteristics. The sixth hypothesis stated that there is a positive relationship between the level of information technology equipments in small and medium-sized enterprises and e-commerce adoption. The results showed a significant relationship between the adoption of e-commerce and the level of information technology equipments. These findings are consistent with the findings of Wang, Wang and Cheng, and gravure and Gslar. According to the results of the stepwise regression model, the independent variable-the level of innovation- predicts $45 \%$ of the dependent variables- e-commerce adoption. Therefore, developing and adopting policies that encourage the culture of innovation and creativity in small and medium-sized enterprises can be the main priorities of managers in the development of e-commerce. Correct policy making in this area requires further research and analysis.

Considering the positive and significant relationship between using information technology and e-commerce adoption, it is recommended that managers plan for the development and use of information technology resources. The program may include items such as expanding the use of computers in daily activities, provision of educational programs in the field of internet and computer, and attracting skilled and expert individuals in the field of information technology. 
Considering the positive and significant relationship between organizational complexity and acceptance of electronic commerce, it is recommended that managers use flexible and network form of organizational structures. It may include activities such as teamwork, cooperation with competitors in some of the activities, outsourcing some activities to other companies, and monitor and control based on the performance.

\section{References}

Elahi, Shaban; Fathi, S ;Azizi, Shahriar; Ebrahimi, Maryam; Shahrivar, Shahrukh; Heidari, Bahman; Salehi, Ali ; and Khosravi, A (2008). Model designed to measure the readiness of companies to deploy e-commerce, First Printing ,Tehran: Institute for Trade Studies and Research

Gover, V., \& Goslar, M. D.(1993). "The initiation, adoption, and implementation of telecommunications technologies in U.S. organizations". Journal of Management Information Systems, Vol. 10, No. 1, pp.141-163.

Lin, C. S.(2006). Organizational, technological, and environmental determinants of electronic commerce adoption in small and medium enterprises in Taiwan. Unpublished doctoral dissertation, Lynn University, Taiwan.

MacGregor, R. C. (2006). "The role of strategic alliances in the ongoing use of electronic commerce technology in regional small business". Journal of Electronic Commerce in Organizations, Vol. 2, No. 1, pp. 1-14.

Nasco, S.A., Toled, E.G.,\&Mykytyn, P.P. (2008). "Predicting electronic commerce adoption in Chilean SMEs". Journal of Business Research, Vol. 61, pp. 697-705.

Nasco, S.A., Toled, E.G.,\&Mykytyn, P.P. (2008). "Predicting electronic commerce adoption in Chilean SMEs". Journal of Business Research, Vol. 61, pp. 697-705.

Sadeghi, Mahdi and Nouri Toopkanloo, Zahra (2005). Global e-commerce and information technology. Mashhad. Sokhan Gostar

SubbaRoa, S., Glenn Metts., \& Mora Mong, C.A. (2003). "Electronic commerce development in small and medium sized enterprises:A stage model and its implications". Business Process Mangement Journal, Vol. 9, No. 1, pp. 11-32.

Tapscott, D.(1996). The digital economy: Promise and peril in the age of networked intelligence.NewYork: McGraw-Hill.

Turban, E.,Lee, J., King, D., \& Chung, H. M.(2008). Electronic commerce: A managerial perspective. Upper Saddle River, NJ: Prentice Hall. 
Vilaseca, J., Torrent, J., Meseguer, A., \& Rodriguez, I. (2007). “An integrated model of the adoption and extent of e-commerce in firms". International Advances in Economic Research, Vol. 13, pp. 222-241.

Wang, S.C. (2001). "Individual / organizational characteristics and intention to adopt ecommerce: A study based on innovation adoption theory". Unpublished doctoral dissertation, The Chinese University of Hong Kong, Hong Kong.

Wang, S., \& Cheung, W.(2004). "E-commerce adoption by travel agencies: Prime candidates for mobile e-commerce". International Journal of Electronic commerce, Vol. 8, No.3, pp. 43-63. 